\title{
Mathematics Anxiety Level of Pre-Service Elementary School Teachers During Online Learning in the Covid-19 Pandemic
}

\author{
Imanuel Yosafat Hadi Manapa \\ Universitas Tribuana Kalabahi \\ manuelmathematics@gmail.com
}

Received: May 2021. Accepted: June 2021. Published: July 2021.

\begin{abstract}
The purpose of this study was to find out students' math anxiety levels and compare math anxiety levels between semesters. This research was conducted because of the impact of online lectures during the pandemic era, namely the decrease in student achievement in all mathematics courses. This research was conducted in the Primary School Teacher Education Study Program of Tribuana Kalabahi University. The research method used is a quantitative research method with a comparative approach. The subjects of this study were 157 students who were in semesters 2 and 4. The instrument used in this study was the RevisedMathematics Anxiety Survey (R-MAX) developed by Bursal and Paznokas. In this study, the instrument feasibility test is still conducted using the validity of the content and reliability test of the instrument. This instrument is declared valid in content according to mathematicians. In addition, the instrument is declared reliable using the Cronbach Alpha method with a reliability coefficient of 0.911 . The results showed that students' math anxiety levels were at moderate levels. Cumulatively, $71.3 \%$ of students had moderate to very high anxiety disorders. Further comparative test results using independent $t$-tests showed that there was no difference in the average student math anxiety score based on semester class. Special attention is needed from the University considering the impact of student anxiety on learning achievements and pedagogic competencies in the future.

Keywords: online learning, student math anxiety.
\end{abstract}

How to Cite: Manapa, I. Y. H. (2021). Mathematics Anxiety Level of Pre-Service Elementary School Teachers During Online Learning in the Covid-19 Pandemic. Journal of Medives: Journal of Mathematics Education IKIP Veteran Semarang, 5(2), 339-352. 


\section{PENDAHULUAN}

Pandemi COVID-19 merupakan babak baru permasalahan yang menyerang seluruh aspek vital kehidupan termasuk di dalamnya pendidikan. Dampak ini berimbas langsung pada penyelenggaraan pembelajaran di setiap jenjang pendidikan. Adanya pembatasan sosial dan implementasi protokol kesehatan yang dianjurkan oleh pemerintah dilakukan sebagai upaya pencegahan penyebaran penyebaran virus ini. Faktor-faktor yang menjadi penentu kualitas pembelajaran ditentukan oleh faktor eksternal dan faktor internal yang mempengaruhinya. Akibat dari wabah pandemi ini adalah munculnya tantangan baru kualitas pembelajaran yang sedang terancam oleh faktor eksternal (Bozkurt \& Sharma, 2020). Intititusi dan semua komponen di dalamnya harus segera mencari solusi yang terbaik untuk mengatasi dampak pandemi COVID-19 terutama pada aspek pembelajaran (Daniel, 2020). Pada akhirnya pelaksanaan pembelajaran dilakukan secara daring sebagai pemenuhan syarat protokol kesehatan yang dicanangkan oleh pemerintah (Setiawan, 2020). Pembelajaran secara daring dianjurkan di setiap jenjang pendidikan mulai dari pendidikan dasar hingga pendidikan tinggi. Pelaksanaan pembelajaran secara daring membutuhkan proses adaptasi karena belum pernah dilakukan secara serentak dengan waktu yang cukup lama.

Pelaksanaan pembelajaran secara tatap muka dan daring memiliki kelebihan dan kelemahan masing-masing dan dapat juga menjadi pelengkap satu sama lain (Ananga \& Biney, 2017). Pembela- jaran daring di era pandemi membutuhkan adaptasi karena tidak mudah mengubah paradigma dalam waktu singkat terkait proses pembelajaran yang telah dilakukan secara tatap muka selama ini (Cassibba et al., 2021). Ditingkat universitas, pembelajaran daring di era pandemi menghadirkan permasalahan baru yang bersumber dari dosen maupun mahasiswa (Irfan et al., 2020). Permasalahan tersebut berasal dari pelaksanaan pembelajaran daring, aktivitas mahasiswa selama perkuliahan, kompetensi pedagogis, dan kualitas konten mata kuliah (Diningrat et al., 2020). Dilain sisi, penggunaan teknologi pembelajaran daring perlu untuk memperhatikan manajemen waktu, pendekatan pedagogis yang sesuai, dan pengalaman dosen untuk menggunakan teknologi pembelajaran daring (Mercader \& Gairín, 2020). Akibat dari pembelajaran ini mahasiswa merasa cemas akan kualitas perkuliahan dan prestasi belajar mereka karena banyaknya tugas yang diberikan (Dewi, 2020). Kecemasan merupakan hal yang wajar jika tidak berlebihan, namun akan menjadi masalah serius jika dirasakan berlebihan(Azizah et al., 2019).

Kecemasan pada mahasiswa dirasakan pada di setiap mata kuliah tak terkecuali matematika. Kecemasan akan matematika dapat disebabkan oleh peralihan proses pembelajaran secara tatap muka menjadi pembelajaran secara daring dan perbedaan capaian kurikulum selama masa pandemi (Lailiyah et al., 2021). Kecemasan matematika adalah perasaan tegang dan takut yang menggangu performa kinerja, memanipulasi angka, dan pemecahan permasalahan 
matematika dalam kehidupan sehari-hari maupun pada lingkungan akademis (Khasawneh et al., 2021). Kecemasan matematika memiliki pengaruh negatif terhadap pembelajaran matematika dan prestasi belajar mahasiswa. Semakin tinggi kecemasan mahasiswa terhadap matematika maka akan semakin rendah prestasi belajar yang akan dicapai (Guita \& Tan, 2018). Pada kondisi tertentu, apabila kecemasan matematika sudah berada pada level yang tinggi maka diperlukan bantuan konselor untuk mengurangi dampaknya serta untuk menumbuhkan kembali efikasi diri (Simorangkir et al., 2021). Secara khusus bagi mahasiswa calon guru, kecemasan matematika sangat berpengaruh pada kompetensi pedagogik mereka yang berimbas pada cara mengajar mereka. Mengetahui tingkat kecemasan guru dan calon guru merupakan hal yang penting untuk diketahui secara spesifik faktor penentu kecemasan agar dapat dikurangi (Gresham, 2018). Hal ini sangat bermanfaat karena guru dengan tingkat kecemasan matematika yang rendah memiliki cara efektif untuk membangun perasaaan nyaman yang dapat mengurangi kecemasan siswanya (Yavuz, 2018). Hal ini berarti kecemasan calon guru akan matematika turut berpengaruh pada sikap siswa mereka terhadap matematika nantinya (Gürbüz \& Y1ldırım, 2016). Lebih lanjut, terdapat hubungan positif antara tingkat kecemasan matematika yang dimiliki guru dengan kecemasan mengajarnya serta prestasi belajar matematika siswa mereka (Hadley \& Dorward, 2011).

Kecemasan akan matematika pada guru dan calon guru umum terjadi dan lebih banyak fakta akan hal ini dibandingkan dengan mahasiswa jurusan lainnya (Sanders et al., 2019). Faktor penyebab kecemasan matematika dapat berasal dari faktor sosial, kognitif, dan akademis (Ruff \& Boes, 2014). Lebih lanjut, kriteria kecemasan matematika terbagi menjadi empat domain yakni domain kognitif, sikap, somatik, dan representasi (Rizta \& Antari, 2019). Selain itu, kurangnya interaksi pada proses pembelajaran juga turut menjadi faktor penyebab meningkatnya kecemasan terhadap matematika (Allen \& Vallée-Tourangeau, 2016). Secara khusus, kecemasan matematika bagi calon guru terbagi menjadi dua domain yaitu kecemasan umum dan kecemasan mengajar matematika. Kecemasan umum berkaitan dengan pengetahuan matematis dan kepercayaaan diri akan matematika, sedangkan kecemasan mengajar matematika berkaitan dengan kecemasan individu terkait dengan kemampuan mengajar matematikanya (Dzulfikar, 2016). Mahasiswa dengan gangguan kecemasan umum akan merasa cemas ketika menghadapi ujian matematika. Gangguan kecemasan matematika mahasiswa saat menghadapi ujian matematika dapat meluas dan mempengaruhi konsentrasi mahasiswa pada ujian mata kuliah lainnya (Lewis, 2020). Kecemasan matematika bagi mahasiswa calon guru yang akan menjalani praktik mengajar dapat mengakibatkan rasa kurang percaya diri, gaya mengajar yang kaku, dan kurang melihatkan siswa dalam proses pembelajaran (Finlayson, 2014).

Penelitian ini dilakukan di Universitas Tribuana Kalabahi pada 
Fakultas Keguruan dan Ilmu Pendidikan Program Studi Pendidikan Guru Sekolah Dasar. Dipilihnya mahasiswa calon guru sekolah dasar karena hanya pada program studi ini yang mengharuskan mahasiswa memiliki kompetensi matematika. Selain itu, penelitian menjadi begitu penting untuk dilakukan karena hasil evaluasi prestasi belajar mahasiswa yang menurun dratis selama era pandemi COVID-19 jika dibandingkan dengan sebelum era ini. Pada masa pandemi ini, berdasarkan hasil evaluasi semester ganjil diperoleh lebih dari $70 \%$ hasil belajar mahasiswa pada mata kuliah matematika yakni konsep dasar matematika, geometri dan pengukuran, serta statistika untuk penelitian tidak mencapai standar minimum kelulusan yang ditentukan oleh universitas. Permasalahan pada hasil evaluasi ini diduga disebabkan oleh pembelajaran secara daring selama era pandemi. Menurunnya hasil evaluasi ini tidak pernah dijumpai sebelumnya dan hanya terjadi selama era pandemi.

Sangat penting untuk mengidentifikasi level kecemasan matematika mahasiswa sejak semester awal. Hal ini bertujuan untuk mengurangi bahkan mengatasi kecemasan mahasiswa di semester-semester selanjutnya. Tujuan utama dari program studi pendidikan guru sekolah dasar adalah untuk menghasilkan lulusan yang berkompeten pada bidangnya. Program studi ini baru berjalan empat semester. Selain itu, untuk mahasiswa semester dua memulai perkuliahan secara daring sejak tahun ajaran baru karena pandemi ini. Saat ini aktivitas perkuliahan telah berjalan secara normal, namun demikian sangat penting untuk mengidentifikasi level kecemasan mahasiswa dan membandingkan level kecemasan mahasiswa antar semester. Hal ini bertujuan agar imbas dari kecemasan matematika mahasiswa dapat segera dicegah mengingat karakteristik mata kuliah matematika yang akan saling berkaitan pada semester-semester selanjutnya.

Dewasa ini, selain karena tidak efektifnya aktivitas pembelajaran di era pandemi, kecemasan matematika juga turut menjadi perhatian sebagai objek penelitian. Berbagai penelitian terkait kecemasan matematika dengan tujuan yang beragam telah dilakukan mengingat dampak yang ditimbulkan oleh hal ini. Penelitian dengan tujuan untuk menginvestigasi hubungan antara kecemasan matematika mahasiswa terhadap performa mereka, level kecemasan mahasiswa berdasarkan program studi, dan mengetahui perilaku mahasiswa terhadap matematika (Siaw et al., 2020). Penelitian dengan tujuan untuk mengetahui dampak kecemasan matematika berdasarkan pada perbedaan gender (Sonia et al., 2020). Penelitian dengan tujuan untuk mengidentifikasi tingkat kecemasan sebagai imbas dari pandemi COVID-19 (Mendoza et al., 2021). Hasil penelitian tersebut menunjukan pembelajaran online selama era pandemi membatasi pemahaman dan menimalkan kecemasan mahasiswa akan matematika. Persamaan penelitian ini dengan penelitian yang dilakukan sebelumnya adalah penelitian ini bertujuan untuk mengidentifikasi level kecemasan matematika mahasiswa. Perbedaan penelitian ini dengan penelitian sebelumnya adalah penelitian sebelum- 
nya dilakukan sebelum dan selama masa pandemi. Penelitian ini dilakukan juga dilakukan selama masa pandemi namun Universitas Tribuana telah melaksanakan aktivitas pembelajaran secara tatap muka. Lebih lanjut penelitian ini bertujuan untuk membandingkan level kecemasan mahasiswa antar semester namun dalam satu program studi. Diharapkan hasil penelitian ini dapat digunakan sebagai acuan untuk memberikan tindakan preventif dan penanggulangan terhadap kecemasan matematika mahasiswa.

\section{METODE PENELITIAN}

Penelitian ini adalah penelitian kuantitatif dengan pendekatan komparatif. Penelitian ini bertujuan untuk mengetahui level kecemasan matematika mahasiswa dan membandingkan kecemasan matematika mahasiswa antar tingkatan semester. Subjek penelitian dari penelitian ini adalah mahasiswa Program Studi Pendidikan Guru Sekolah Dasar di Universitas Tribuana Kalabahi semester 2 dan 4 . Teknik sampling yang digunakan pada penelitian ini adalah teknik proportionate stratified random sampling. Jumlah total sampel responden penelitian yaitu sebanyak 157 mahasiswa yang terdiri dari 83 mahasiswa pada semester 2 dan 74 mahasiswa pada semester 4 . Penelitian ini dilakukan pada bulan Februari hingga April 2021.

Instrumen penelitian yang digunakan pada penelitian ini adalah The Revised-Mathematics Anxiety Survey (R-MANX) berupa angket yang di kembangkan oleh Bursal dan Paznokas. Instrumen ini memiliki 30 butir pertanyaan berskala likert dengan 5 skala pengukuran yaitu dari skala 1 (tidak pernah) hingga skala 5 (selalu). Dengan demikian skor minimum yang dapat dicapai oleh masing-masing resopnden adalah 30 dan skor maksimum adalah 150. Instrumen ini terdiri dari 23 pernyataan negatif dan 7 pernyataan positif. Agar tidak terjadi kesalahan pemberian skor maka semua butir pernyataan positif dari instrumen ini diubah menjadi pernyataan negatif. Selain itu, oleh karena instrumen asli berbahasa Inggris maka semua pernyataan pada instrumen ini diubah terlebih dahulu menjadi pernyataan dengan menggunakan bahasa Indonesia. Hal ini bertujuan untuk menghindari kesalahan pengisian angket dari sisi bahasa. Kesesuaian makna pernyataanpernyataan pada instrumen tersebut telah konfirmsi kesesuaian maknanya oleh dua orang dosen dari program studi pendidikan bahasa Inggris.

Instrumen ini telah memenuhi standar kelayakan instrumen yakni validitas dan reliabilitas untuk mengukur level kecemasan matematika berdasarkan situasi akademik di lembaga pendidikan (Bursal \& Paznokas, 2006). Lebih lanjut, kesesuaian instrumen penelitian untuk mengukur level kecemasan calon guru ditunjukan oleh beberapa laporan hasil penelitian (Yuniarti et al., 2014), (Nanna, 2021), dan (Van der Sandt \& O'brien, 2017). Untuk memastikannya maka pada penelitian ini tetap dilakukan uji validitas dan reliabilitas intrumen. Uji validitas menggunakan uji validitas pakar oleh 2 orang dosen matematika. Setelah instrumen dinyatakan valid oleh 
pakar, selanjutnya dilakukan uji coba instrumen pada 30 orang mahasiswa. Uji coba instrumen bertujuan untuk mengetahui koefisien reliabilitas intrumen menggunakan metode Cronbach Alpha. Hasil uji reliabilitas intrumen diperoleh koefisien reliabilitas sebesar 0,911 dengan demikian instrumen ini dinyatakan reliabel.

Skor kecemasan mahasiswa $(\mathrm{X})$ dikategorikan menjadi lima level yakni kecemasan matematika sangat tinggi, tinggi, sedang, rendah, dan sangat rendah. Pengklasifikasian kategori kecemasan berdasarkan pada nilai ratarata kecemasan matematika mahasiswa $(\underline{X})$ dan standar deviasi $\left(\mathrm{S}_{\mathrm{D}}\right)$ dapat dilihat pada Tabel 1.

Tabel 1. Klasifikasi Kategori Kecemasan Matematika Mahasiswa

\begin{tabular}{ccc}
\hline No & Interval & Kategori \\
\hline 1. & $\mathrm{X} \geq \underline{X}+1,5 \mathrm{~S}_{\mathrm{D}}$ & $\begin{array}{c}\text { Sangat } \\
\text { Tinggi }\end{array}$ \\
2. & $\underline{X}+0,5 \mathrm{~S}_{\mathrm{D}}<\mathrm{X} \leq \underline{X}+1,5 \mathrm{~S}_{\mathrm{D}}$ & Tinggi \\
3. & $\underline{X}-0,5 \mathrm{~S}_{\mathrm{D}}<\mathrm{X} \leq \underline{X}+0,5 \mathrm{~S}_{\mathrm{D}}$ & Sedang \\
4. & $\underline{X}-1,5 \mathrm{~S}_{\mathrm{D}}<\mathrm{X} \leq \mathrm{M}-0,5 \mathrm{~S}_{\mathrm{D}}$ & Rendah \\
5. & $\mathrm{X} \leq \underline{X}-1,5 \mathrm{~S}$ & Sangat \\
& & Rendah
\end{tabular}

Setelah data diklasifikasikan selanjutnya dilakukan uji komparasi perbedaan rerata untuk mengetahui perbedaan rerata kecemasan mahasiswa antar semester. Uji komparasi dilakukan menggunakan uji independent sample ttest. Sebelum dilakukan uji independent sample t-test, terlebih dahulu dilakukan uji prasyarat uji independent sample ttest yaitu uji normalitas dan uji homogenitas pada masing masing kelompok sampel. Analisis data pada penelitian ini dianalisis dengan bantuan program Statistical Package for Social Sciences (SPSS) versi 24.

\section{HASIL DAN PEMBAHASAN}

\section{Level Kecemasan Matematika Maha- siswa Calon Guru}

Hasil kategorisasi level kecemasan matematika mahasiswa dapat dilihat pada Tabel 2.

Tabel 2. Distribusi Frekuensi dan Persentase Kecemasan Matematika Mahasiswa

\begin{tabular}{ccccc}
\hline No & Kategori & Frekuensi & $\%$ & $\begin{array}{c}\% \\
\text { Kumulatif }\end{array}$ \\
\hline 1 & $\begin{array}{l}\text { Sangat } \\
\text { Tinggi }\end{array}$ & 14 & 8.9 & 8.9 \\
2 & Tinggi & 29 & 18.5 & 27.4 \\
3 & Sedang & 69 & 43.9 & 71.3 \\
4 & Rendah & 30 & 19.1 & 90.4 \\
5 & Sangat & 15 & 9.6 & 100 \\
\hline
\end{tabular}

Distribusi mahasiswa pada masing-masing kategori kecemasan matematika yaitu mahasiswa dengan kategori kecemasan matematika sangat tinggi sebanyak 14 orang dengan persentase $8.9 \%$, kecemasan matematika tinggi sebanyak 29 orang dengan persentase $18.5 \%$, kecemasan matematika sedang sebanyak 69 orang dengan persentase 43.9\%, kecemasan matematika rendah sebanyak 30 orang dengan persentase 19.1\%, dan kecemasan sangat rendah sebanyak 15 orang dengan persentase $9,6 \%$. Selanjutnya ditentukan level kecemasan matematika mahasiswa secara keseluruhan ditentukan berdasarkan hasil pengolahan uji statistik deskriptif yang disajikan pada Tabel 3. 


\begin{tabular}{|c|c|}
\hline \multicolumn{2}{|c|}{ Kecemasan Matematika Mahasiswa } \\
\hline $\mathrm{N}$ & 157 \\
\hline Rata -rata & 93.24 \\
\hline Median & 92.00 \\
\hline Modus & 102 \\
\hline Standar Deviasi & 18.79 \\
\hline Variansi & 353.26 \\
\hline Nilai Maksimum & 138 \\
\hline Nilai Minimum & 55 \\
\hline Kuartil 1 & 80 \\
\hline Kuartil 2 & 92 \\
\hline Kuartil 3 & 104 \\
\hline
\end{tabular}

Berdasarkan hasil analisis deskriptif data pada Tabel 3 diketahui bahwa nilai rata-rata skor kecemasan matematika mahasiswa adalah 93.24. Selanjutnya, jika meninjau kategori kecemasan pada Tabel 1 maka dapat disimpulkan bahwa rata-rata kecemasan matematika mahasiswa berada pada kategori sedang. Walaupun kecemasan mahasiswa berada pada level sedang namun telah berpotensi memiliki masalah pada domain kognitif dan pemahaman matematis (Ismawati et al., 2015). Permasalahan tersebut dapat membuat mahasiswa merasa bahwa kompetensi pengetahuan dan pemahaman mereka akan matematika masih kurang. Hal ini akan sangat berpengaruh pada kompetensi pedagogiknya kelak apabila tidak segera diatasi. Mengacu pada hal tersebut maka sebaiknya mahasiswa tersebut diberikan pengetahuan pedagogik, pengetahuan matematika, dan pengalaman mengajar yang lebih banyak. Hal ini bertujuan agar kecemasan matematika dapat berkurang dan dpat menjadi guru yang profesional nantinya.

Berdasarkan Tabel 3 diketahui bahwa mayoritas mahasiswa berada pada kategori kecemasan matematika sedang yakni sebesar 43,9\% dengan persentasi kumulatif kecemasan matematika mahasiswa dari sedang hingga level kecemasan sangat tinggi sebesar $71.3 \%$. Oleh karena akibat dari kecemasan matematika bagi mahasiswa telah muncul pada kategori kecemasan matematika level sedang, maka dapat disimpulkan bahwa sebanyak 71.3\% mahasiswa akan menemui masalah terkait matematika selama proses perkuliahan. Telah dijelaskan sebelumnya bahwa pelaksanaan aktivitas pembelajaran daring selama masa pademi yang tidak optimal maka diperoleh dugaan bahwa level kecemasan matematika mahasiswa yang ada adalah akibat dari aktivitas pembelajaran daring. Hal ini diperkuat dengan menurunnya prestasi belajar mahasiswa jika dibandingkan dengan sebelum masa pandemi. Hasil evaluasi pada akhir semester ganjil menunjukan lebih dari $70 \%$ mahasiswa mengalami penurunan prestasi belajarnya.

Selama era pandemi, dosen maupun mahasiswa beradaptasi terhadap transisi perubahan aktivitas pembelajaran dari tatap muka menjadi daring. Faktor-faktor penyebab kecemasan matematika mahasiswa pendidikan guru calon guru diakibatkan oleh frekuensi belajar yang minim, situasi belajar yang tidak kondusif, kompleksitas materi, dan tuntutan hasil belajar (Rawa \& Mastika Yasa, 2019). Faktor-faktor penyebab kecemasan matematika tersebut semuanya terjadi selama aktivitas perkuliahan di era pandemi. Hasil penelitian menunjukan bahwa di era pandemi mahasiswa memilih agar aktivitas perkuliahan matematika sebaiknya 
dilakukan secara blended learning (Agus \& La Hadi, 2020). Aktivitas perkuliahan secara daring yang dimaksud adalah perpaduan antara pembelajaran secara tatap muka dan daring. Untuk mencegah penyebaran virus ini maka sebaiknya perkuliahan secara tatap muka dilakukan secara shifting atau bergantian dengan jumlah mahasiswa di dalam kelas dibatasi dan tetap mematuhi protokol kesehatan. Selain itu, beberapa solusi yang dapat digunakan untuk mengurangi kecemasan matematika mahasiswa calon guru adalah dosen hendaknya memberikan lebih banyak tugas, menghadirkan sikap positif mahasiswa akan matematika, memberikan perhatian khusus bagi mahasiswa dengan tingkat kecemasan sedang hingga sangat tinggi, melakukan banyak penelitian terkait kecemasan matematika, matematika dijadikan sebagai program mata kuliah dasar atau sebagai bahan matrikulasi, dan pembimbingan kepada calon mahasiswa untuk memilih program jurusan yang sesuai bagi calon mahasiswa yang memiliki gangguan kecemasan matematika (Cumhur et al., 2019).

Kecemasan matematika yang ada pada mahasiswa calon guru akan mempengaruhi kesiapan mereka untuk mengajar (Sintawati \& Abdurrahman, 2019). Bagi mahasiswa calon guru sekolah dasar perlu dicarikan solusi kecemasan matematika agar kelak siswa mereka dapat terhindar dari masalah kecemasan matematika (Hartatik \& Fitriyah, 2017). Sebagai solusi, pihak universitas terutama program studi hendaknya menyediakan program perkuliahan yang dapat memfasilitasi calon guru untuk menguasai teknik mengajar yang efektif dan bermakna bagi siswa (Rahayu, Sartono, et al., 2019). Lebih lanjut, selama proses perkuliahan mahasiswa dengan gangguan kecemasan matematika akan lebih terbantu proses belajar mereka ketika belajar bersama mahasiswa lainnya (Bjälkebring, 2019). Dengan demikian, sebaiknya proses perkuliahan selama era pandemi didesain agar terciptanya aktivitas diskusi antar mahasiswa walaupun dengan menggunakan media pembelajaran daring. Selain itu, apabila perkuliahan dilakukan secara blended maka sebaiknya perkuliahan secara tatap muka maupun secara daring didesain menggunakan model pembelajaran kooperatif maupun kolaboratif.

\section{Perbedaan Rerata Level Kecemasan Mahasiswa Antar Semester}

Sebelum dilakukan uji komparasi rerata level kecemasan matematika dengan menggunakan uji perbedaan rerata dengan menggunakan statiststik uji independent sample t-test, perlu dilakukan uji prasyarat yaitu uji normalitas dan homogenitas pada masing masing kelompok. Hasil uji normalitas dan homogenitas pada masing-masing kelompok dapat dilihat pada Tabel 4.

Tabel 4. Hasil Uji Normalitas Kecemasan Matematika Berdasarkan

\begin{tabular}{cccc}
\hline \multirow{2}{*}{ Semester } & \multicolumn{4}{c}{ Kolmogorov-Smirnov } \\
& Statistic & Df & Sig \\
\hline II & 0.050 & 83 & 0.200 \\
IV & 0.084 & 74 & 0.200 \\
\hline
\end{tabular}

Hasil dari uji normalitas berdasarkan tingkatan semester mahasiswa dengan menggunakan uji Kolmogorov- 
smirnov diperoleh nilai signifikasi pada masing-masing semester sebesar 0.200 . Hal ini menunjukan bahwa data kecemasan matematika mahasiswa untuk masing-masing semester terdistribusi normal karena nilai signifikasi uji Kolmogorov-smirnov lebih besar dari 0.05 .

Tabel 5. Hasil Uji Homogenitas Kecemasan Matematika Berdasarkan Semester

\begin{tabular}{cccc}
\hline $\begin{array}{c}\text { Levene } \\
\text { Statistic }\end{array}$ & df1 & df2 & Sig. \\
\hline 2.599 & 1 & 15 & 0.10 \\
& & 5 & 9 \\
\hline
\end{tabular}

Pengambilan keputusan uji pada uji homogenitas dengan menggunakan uji levene ditentukam berdasarkan nilai signifikasinya. Apabila nilai signifikasi lebih besar dari 0.05 maka variansi kedua kelompok dikatakan homogen. Sebaliknya, apabila nilai signifikasi lebih kecil dari 0.05 maka variansi kedua kelompok dikatakan tidak homogen. Berdasarkan nilai signifikasi pada Tabel 5, yakni sebesar 0.109, maka dapat disimpulkan bahwa variansi kedua kelompok mahasiswa berdasarkan perbedaan tingkatan semester adalah homogen.

Diketahui bahwa variansi kecemasan matematika mahasiswa pada dua kelompok semester tersebut homogen. Dengan demikian pengambilan keputusan uji independent t-test pada Tabel 6 diambil berdasarkan equal variances assumed. Berdasarkan Tabel 6 diketahui bahwa nilai signifikansi yang diperoleh sebesar 0.274. Nilai signifikasi yang diperoleh tersebut lebih besar dari 0.05 sehingga $\mathrm{H}_{\mathrm{o}}$ diterima. Dengan demikian dapat disimpulkan bahwa tidak terdapat perbedaan rerata kecemasan matematika mahasiswa antara mahasiswa semester 2 dan semester 4. Hasil penelitian ini sejalan dengan penelitian sebelumnya yang menunjukan bahwa tidak terdapat perbedaan rerata kecemasan matematika mahasiswa calon guru sekolah dasar dengan perbedaan semest-er angkatan (Rahayu, Mustadi, et al., 2019). Mahasiswa calon guru sekolah dasar diwajibkan untuk memiliki kompetensi matematika pada ruang lingkup sekolah dasar. Mata kuliah dasar matematika hingga pengembangannya diprogramkan guna menghasilkan pendidik yang berkompeten. Mata kuliah matematika yang diprogramkan oleh program studi berbeda-beda dan disesuaikan dengan kebutuhan pendidikan dasar. Kompleksitas pada mata kuliah matematika berbeda pada tiap semester. Semakin tinggi semester semakin kompleks

Tabel 6. Hasil Uji Independent T-Test Kecemasan Matematika Berdasarkan Semester

\begin{tabular}{|c|c|c|c|c|c|c|c|c|}
\hline & & \multirow[t]{2}{*}{$\mathrm{t}$} & \multirow[t]{2}{*}{ df } & \multirow[t]{2}{*}{$\begin{array}{l}\text { Sig. } \\
(2- \\
\text { tailed })\end{array}$} & \multirow[t]{2}{*}{$\begin{array}{c}\text { Mean } \\
\text { Difference }\end{array}$} & \multirow[t]{2}{*}{$\begin{array}{l}\text { Std. Error } \\
\text { Difference }\end{array}$} & \multicolumn{2}{|c|}{$\begin{array}{c}95 \% \text { Confidence } \\
\text { Interval of the } \\
\text { Difference }\end{array}$} \\
\hline & & & & & & & Lower & Upper \\
\hline $\begin{array}{l}\text { Skor } \\
\text { Kecemasan } \\
\text { Matematika }\end{array}$ & $\begin{array}{l}\text { Equal } \\
\text { variances } \\
\text { assumed }\end{array}$ & -1.097 & 155 & 0.274 & -3.295 & 3.003 & -9.227 & 2.637 \\
\hline Mahasiswa & $\begin{array}{l}\text { Equal } \\
\text { variances } \\
\text { not } \\
\text { assumed }\end{array}$ & -1.088 & 144.76 & 0.279 & -3.295 & 3.029 & -9.283 & 2.692 \\
\hline
\end{tabular}


kajian matematika yang dipelajari. Tidak adanya perbedaan level kecemasan matematika mahasiswa berdasarkan angkatan semester mengindikasikan kecemasan matematika tidak dipengaruhi oleh semakin banyak mata kuliah yang telah diambil. Kecemasan matematika pada mahasiswa dikhawatirkan akan mempengaruhi mahasiswa ketika telah menjadi seorang guru terkait dengan kompetensi pedagodiknya.

Karakteristik matematika yang memiliki keterkaitan antar konsep di dalamnya sehingga apabila mahasiswa tidak menguasai konsep-konsep matematika secara mendalam pada mata kuliah prasyarat maka akan berdampak juga pada mata kuliah pengembangannya. Semakin banyak mata kuliah matematika yang diambil tidak mereduksi kecemasan yang dimiliki oleh mahasiswa. Hal ini disimpulkan berdasarkan pada tidak adanya perbedaan level kecemasan yang dimiliki oleh mahasiswa berdasarkan perbedaan semester. Gangguan ini harus segera dideteksi sejak awal semester melalui performa mahasiswa terhadap matematika karena kemampuan matematika dapat digunakan untuk memprediksi level kecemasan matematika (Namkung et al., 2019). Lebih lanjut, keyakinan diri mahasiswa akan kemampuannya terhadap matematika juga dapat gunakan sebagai prediktor kecemasan mereka (Gonzalez-DeHass et al., 2017). Persepsi buruk mahasiswa dapat berasal dari faktor dosen selama proses perkuliahan. Dosen memegang peran penting yang dapat mengurangi bahkan meniadakan kecemasan mahasiswa (Loviana, 2020). Sebuah saran penelitian lanjutan untuk menganalisis faktor penyebab kecemasan matematika dan analisis kebutuhan tiap-tiap mahasiswa sangat diperlukan. Hal ini bertujuan untuk memperoleh informasi secara mendetail terkait kecemasan matematika mahasiswa.

\section{PENUTUP}

Hasil penelitian ini menunjukan bahwa level kecemasan matematika berada pada level sedang. Lebih lanjut, hasil penelitian menunjukan bahwa tidak terdapat perbedaan rerata skor kecemasan matematika mahasiswa berdasarkan semester angkatan. Beberapa faktor diduga sebagai penyebab gangguan kecemasan matematika mahasiswa. Beberapa faktor di antaranya adalah kondisi pandemi, pelaksanaan perkuliahan, dan dosen. Faktor-faktor tersebut hanya sebatas dugaan sehingga membutuhkan penelitian lanjutan untuk mengkaji secara mendalam. Selain itu, dibutuhkan analisis kebutuhan setiap mahasiswa khususnya dengan level kecemasan mahasiswa tinggi dan sangat tinggi agar dapat mengatasi kecemasan matematika yang dialami.

\section{DAFTAR PUSTAKA}

Agus, I., \& La Hadi, A. (2020). The Responses of Mathematics PreService Teachers Toward Online Lectures in the Covid-19 Era. Edumatika: Jurnal Riset Pendidikan Matematika, 3(2), 113. https://doi.org/10.32939/ejrpm.v3i 2.584

Allen, M., \& Vallée-Tourangeau, F. (2016). Interactivity Defuses the Impact of Mathematics Anxiety in Primary School Children. 
International Journal of Science and Mathematics Education, 14(8), 1553-1566.

https://doi.org/10.1007/s10763015-9659-9

Ananga, P., \& Biney, I. K. (2017). Comparing Face-To-Face and Online Teaching In Higher Education. MIER Journal of Educational Studies, Trends \& Practices, 7(2), 165-179.

Azizah, L. N., Mahmudi, A., \& Retnawati, H. (2019). Profile of students' mathematics anxiety. Journal of Physics: Conference Series, 1320(1), 1-6. https://doi.org/10.1088/17426596/1320/1/012105

Bjälkebring, P. (2019). Math Anxiety at the University: What Forms of Teaching and Learning Statistics in Higher Education Can Help Students With Math Anxiety? Frontiers in Education, 4(30), 1-5. https://doi.org/10.3389/feduc.2019. 00030

Bozkurt, A., \& Sharma, R. C. (2020). Emergency remote teaching in a time of global crisis due to CoronaVirus pandemic. Asian Journal of Distance Education, 15(1), i-vi. https://doi.org/10.5281/zenodo.377 8083

Bursal, M., \& Paznokas, L. (2006). Mathematics Anxiety and Preservice Elementary Teachers' Confidence to Teach Mathematics and Science. School Science and Mathematics, 106(4), 173-180. https://doi.org/10.1111/j.19498594.2006.tb18073.x

Cassibba, R., Ferrarello, D., Mammana, M. F., Musso, P., Pennisi, M., \& Taranto, E. (2021). Teaching mathematics at distance: A challenge for universities. Education Sciences, 11(1), 1-20. https://doi.org/10.3390/EDUCSCI 11010001

Cumhur, M., Faculty, S., Tezer, M., \& Faculty, S. (2019). Cypriot Journal of Educational dimensional study in the 21st century. 14(2), 222-231.

Daniel, S. J. (2020). Education and the COVID-19 pandemic. Prospects, 49(1-2), 91-96. https://doi.org/10.1007/s11125020-09464-3

Dewi, E. U. (2020). Pengaruh Kecemasan Saat Pembelajaran Daring Masa Pandemi Covid-19 Terhadap Prestasi Belajar Mahasiswa Stikes William Surabaya. Jurnal Keperawatan, 9(1), $\quad 18-23$. https://doi.org/10.47560/kep.v9i1.2 10

Diningrat, S. W. M., Nindya, M. A., \& Salwa. (2020). Emergency online teaching: Early childhood education lecturers' perception of barrier and pedagogical competency. Cakrawala Pendidikan, 39(3), 705-719. https://doi.org/10.21831/cp.v39i3.3 2304

Dzulfikar, A. (2016). Kecemasan Matematika Pada Mahasiswa. Jurnal Matematika Dan Pendidikan Matematika, I(1), 3444.

Finlayson, M. (2014). Addressing math anxiety in the classroom. Improving Schools, 17(1), 99-115. https://doi.org/10.1177/136548021 4521457

Gonzalez-DeHass, A. R., Furner, J. M., Vásquez-Colina, M. D., \& Morris, J. D. (2017). Pre-service elementary teachers' achievement 
goals and their relationship to math anxiety. Learning and Individual Differences, 60(January), 40-45. https://doi.org/10.1016/j.lindif.201 7.10 .002

Gresham, G. (2018). Preservice to inservice: does mathematics anxiety change with teaching experience? Journal of Teacher Education, 69(1), 90-107. https://doi.org/10.1177/002248711 7702580

Guita, G. B., \& Tan, D. A. (2018). Mathematics Anxiety and Students' Academic Achievement in a Reciprocal Learning Environment. International Journal of English and Education, 7(3), 112-123.

Gürbüz, R., \& Y1ldırım, K. (2016). An Investigation of Mathematics Anxiety of Primary School Teachers. Turkish Journal of Computer and Mathematics Education (TURCOMAT), 7(3), 536-536.

https://doi.org/10.16949/turkbilmat .277870

Hadley, K. M., \& Dorward, J. (2011). Investigating the Relationship between Elementary Teacher Mathematics Anxiety, Mathematics Instructional Practices, and Student Mathematics Achievement. Journal of Curriculum and Instruction, 5(2), 27-44. https://doi.org/10.3776/joci.2011.v $5 \mathrm{n} 2 \mathrm{p} 27-44$

Hartatik, S., \& Fitriyah, F. K. (2017). Identifikasi Kecemasan

Matematika Pada Mahasiswa Program Studi Pendidikan Guru Sekolah Dasar. Jurnal Bimbingan Konseling Indonesia, 2(2), 31-33.

Irfan, M., Kusumaningrum, B., Yulia, Y., \& Widodo, S. A. (2020). Challenges During the Pandemic:
Use of E-Learning in Mathematics Learning in Higher Education. Infinity Journal, 9(2), 147. https://doi.org/10.22460/infinity.v9 i2.p147-158

Ismawati, N., Junaedi, I., \& Artikel, I. (2015). Strategi Dan Proses Berpikir Dalam Menyelesaikan Soal Matematika. Unnes Journal of Mathematics Education Research, 4(2), 93-101.

Khasawneh, E., Gosling, C., \& Williams, B. (2021). What impact does maths anxiety have on university students? $B M C$ Psychology, 9(1), 1-9. https://doi.org/10.1186/s40359021-00537-2

Lailiyah, S., Hayat, S., Urifah, S., \& Setyawati, M. (2021). Levels of students' mathematics anxieties and the impacts on online mathematics learning. Cakrawala Pendidikan, 40(1), 107-119. https://doi.org/10.21831/cp.v40i1.3 6437

Lewis, D. (2020). Student Anxiety in Standards-based Grading in Mathematics Courses. Innovative Higher Education, 45(2), 153-164. https://doi.org/10.1007/s10755019-09489-3

Loviana, S. (2020). Identification of Mathematical Anxiety among the Students of Mathematics Department in an Islamic University in Metro Identifikasi Kecemasan Matematika pada Mahasiswa Tadris Matematika IAIN Metro. Elementary, 6(2), 143-154.

Mendoza, D., Cejas, M., Rivas, G., \& Varguillas, C. (2021). Anxiety as a prevailing factor of performance of university mathematics students during the covid-19 pandemic. The 
Education and Science Journal, 23(2), 94-113. https://doi.org/10.17853/19945639-2021-2-94-113

Mercader, C., \& Gairín, J. (2020). University teachers' perception of barriers to the use of digital technologies: the importance of the academic discipline. International Journal of Educational Technology in Higher Education, 17(1). https://doi.org/10.1186/s41239020-0182-x

Namkung, J. M., Peng, P., \& Lin, X. (2019). The Relation Between Mathematics Anxiety and Mathematics Performance Among School-Aged Students: A MetaAnalysis. Review of Educational Research, 89(3), 459-496. https://doi.org/10.3102/003465431 9843494

Nanna, A. W. I. (2021). Profil Perbedaan Level Mathematics Anxiety Mahasiswa Calon Guru Sekolah Dasar. Jurnal Pendidikan Dasar Borneo (Judikdas Borneo), 02(02), 132-138.

Rahayu, L. P., Mustadi, A., \& Sarjiman, P. (2019). An Investigation On PreService Elementary School Teachers' Mathematics Anxiety. An Investigation On Pre-Service Elementary School Teachers' Mathematics Anxiety, 10(1), 111124.

Rahayu, L. P., Sartono, E. K. E., \& Miftakhuddin, M. (2019). The Selfefficacy of Primary School Teachers in Teaching Mathematics: A Comparative Research on Teacher Training Program Products. Mimbar Sekolah Dasar, 6(1), 68. https://doi.org/10.17509/mimbarsd.v6i1.15122
Rawa, N. R., \& Mastika Yasa, P. A. E. (2019). Kecemasan Matematika Pada Mahasiswa Pendidikan Guru Sekolah Dasar. Journal of Education Technology, 2(2), 3645.

https://doi.org/10.23887/jet.v2i2.1 6180

Rizta, A., \& Antari, L. (2019). Tingkat Mathematics Anxiety Pada Mahasiswa Calon Guru Matematika. Jurnal Pendidikan Matematika, 13(1), 9-20. https://doi.org/10.22342/jpm.13.1. 6827.9-20

Ruff, S., \& Boes, S. (2014). The Sum of All Fears: The Effects of Math Anxiety on Math Achievement in Fifth Grade Students and the Implications for School Counselors. Georgia School Counselors Association Journal, 21(1), 1-10.

Sanders, S., Nielsen, W., Sandison, C., \& Forrester, T. (2019). Maths Anxious Pre-Service Teachers' Perspectives of "Doing" Mathematics in a Whiteboard Room. Mathematics Teacher Education \& Development, 21(1), 145-168.

Setiawan, L. D. (2020). Pendidikan Indonesia Di Tengah Pandemi Covid-19. Prosiding Seminar Bahasa Dan Sastra Indonesia (Senasbasa), 4, 432-437.

Siaw, E. S., Shim, G. T. G., Azizan, F. L., \& Shaipullah, N. M. (2020). Understanding the Relationship Between Students' Mathematics Anxiety Levels and Mathematics Performances at the Foundation Level. Journal of Education and Learning, $\quad 10(1), \quad 47$. https://doi.org/10.5539/jel.v10n1p4 7 
Simorangkir, M. R. R., Manalu, R. U., \& Masta, N. (2021). Prediction and Analysis of Mathematics Anxiety Disorders in Adolescents During the Pandemic. Solid State Technology, 64(2), 3042-3049.

Sintawati, M., \& Abdurrahman, G. (2019). Correlation Between Teaching Readiness with Math Anxiety of Primary Pre-Service Teacher. International Conference on Progressive Civil Society (IConProCS), 317(5), 187-192. https://doi.org/10.2991/iconprocs19.2019.39

Sonia, R., Alizamar, A., Bentri, A., \& Putra, F. W. (2020). Rasch Analysis: Students' Mathematics Anxiety and Symptoms. Jurnal Aplikasi IPTEK Indonesia, 4(1), 12-18.

https://doi.org/10.24036/4.14342

van der Sandt, S., \& O’brien, S. (2017). Impact of instructor teaching style and content course on mathematics anxiety of preservice teachers. Journal of Technology Education, 29(1), 95-111. https://doi.org/10.21061/jte.v29i1.a .5

Yavuz, G. (2018). Do prospective teachers have anxieties about teaching mathematics? International Journal of Higher Education, $\quad 7(2), \quad 68-75$. https://doi.org/10.5430/ijhe.v7n2p6 8

Yuniarti, S., Ishak, M. Z., \& Pang, V. (2014). the Relationship Between Mathematical Beliefs and Mathematics Anxiety Among Pre Service Elementary School Teachers in East Borneo, Indonesia. WEI International Academic Conference Proceedings, 237-243. 